\title{
Correction to: Socioeconomic inequalities in suicide mortality before and after the economic recession in Spain
}

\author{
Carme Borrell 1,2,3,4*, Marc Marí-Dell'Olmo ${ }^{1,2,3,4}$, Mercè Gotsens ${ }^{1,2,3}$, Montse Calvo ${ }^{5}$, Maica Rodríguez-Sanz ${ }^{1,2,3,4}$,
} Xavier Bartoll ${ }^{1,3}$ and Santiago Esnaola ${ }^{5}$

\section{Correction to: BMC Public Health https://doi.org/10.1186/s12889-017-4777-7}

It has been highlighted that the original article [1] contained an error in the Funding section. This Correction article shows the incorrect and correct Funding section.

Incorrect:

This article has been partially supported by the project Efectos de la crisis en la salud de la población y sus determinantes en España (PI13/00897), funded by the Instituto de Salud Carlos III.

Correct:

This article has been partially funded by the project Efectos de la crisis en la salud de la población y sus determinantes en España (PI13/00897), funded by the Instituto de Salud Carlos III (co-funded by European Regional Development Fund).

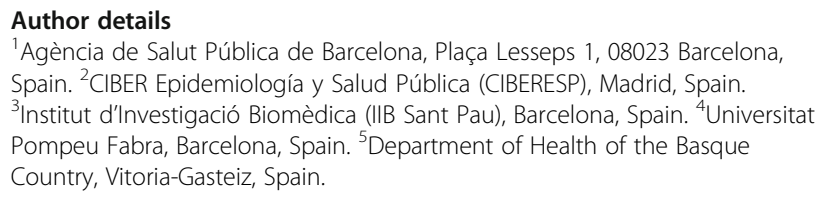

Received: 20 March 2019 Accepted: 20 March 2019

Published online: 01 April 2019

\section{Reference}

1. Borrell, et al. Socioeconomic inequalities in suicide mortality before and after the economic recession in Spain. BMC Public Health. 2017;17:772. https://doi.org/10.1186/s12889-017-4777-7.

\footnotetext{
* Correspondence: cborrell@aspb.cat

${ }^{1}$ Agència de Salut Pública de Barcelona, Plaça Lesseps 1, 08023 Barcelona,

Spain

${ }^{2}$ CIBER Epidemiología y Salud Pública (CIBERESP), Madrid, Spain

Full list of author information is available at the end of the article
}

(c) The Author(s). 2019 Open Access This article is distributed under the terms of the Creative Commons Attribution 4.0 International License (http://creativecommons.org/licenses/by/4.0/), which permits unrestricted use, distribution, and reproduction in any medium, provided you give appropriate credit to the original author(s) and the source, provide a link to the Creative Commons license, and indicate if changes were made. The Creative Commons Public Domain Dedication waiver (http://creativecommons.org/publicdomain/zero/1.0/) applies to the data made available in this article, unless otherwise stated. 